\title{
IoT AND TOUCH-BASED HOME AUTOMATION
}

\author{
Dr. Anitha Chepuru, Associate Professor, G. Narayanamma Institute of Technology and Science, \\ Hyderabad, India, chanitha@gnits.ac.in
}

Ginka Sai Lakshmi Priyanka, Student, 3/4 IT GNITS, Hyderabad, India, priyankaginka@gmail.com Seethala Pradeep Visharika, Student, 3/4 IT GNITS, Hyderabad, India.

Veda Rishitha J, Student, 3/4 IT GNITS, Hyderabad, India.

Vejalla Rishitha, Student, 3/4 IT GNITS, Hyderabad, India.

\begin{abstract}
Internet of Things (IoT) conceptualizes the idea of remotely connecting and monitoring real world objects through the Internet. Home monitoring and home automation are utilized in order to uphold the comfortable living conditions within a home. This IoT project focuses on building a smart wireless home automation system. A lowcost flexible and reliable home automation system with additional security using Arduino microcontroller, with IP connectivity through local Wi-Fi for accessing and controlling devices by authorized user remotely using Smart phone application. The proposed system is server independent and uses Internet of Things to control human desired appliances starting from industrial machine to consumer goods. To demonstrate the effectiveness and feasibility of this system, we present a home automation system using Arduino IDE software and ESP-32 microcontroller as a connectivity module. It helps the user to control various appliances such as light, fan, TV and can take decision based on the feedback of sensors remotely.
\end{abstract}

Keywords - Arduino IDE, ESP-32 microcontroller, Home Automation, Sensor.

\section{INTRODUCTION}

Home automation is the application of computer and information technology that controls home appliances easily. Home Automation system allows the users to manage and handle all the electric appliances. As the technology is developing, people tend to live a comfortable and flexible life. This IOT based home automation helps the people to connect to their appliances from anywhere and at any time. This wireless system uses a mobile application to control the home appliances and function automatically through internet from anywhere around the world globally. This project reduces the electricity, man involvement and wastage of resources. It mainly concentrates on the touch sensor which includes mobile phone for operating the appliances.

\section{LITERATURE REVIEW}

\section{Existing System}

There are systems similar to the proposed system in existence which have sensors for the feasible operating of the appliances. These systems work with human sensors as well as the voice recognitions. Their working with the human sensors are just limited to a particular area which cannot be operated outside the site. . In this competitive world and busy schedule, human cannot spare time to perform his/her daily activities manually. As these systems require the presence of human to control the appliances it may lead to the wastage of power and electricity in the absence of people. Sometimes it is way risky when we forget to turn off the devices and it is not that simple to stop our work and rush to the site to turn off them. It also time consuming. The most common thing that we need to do is switching ON/OFF the loads without much human involvement. During our literature survey we have come across various home automation technologies where different authors have mentioned different technologies that they have used for their project implementation.

- Ali Ziya Alkar in 2005 introduced a model on secure wireless home automation which was made using the unified modelling language. They have provided security with authorization whereas unauthorized people cannot have the access to the system.

- R. Piyare in 2011 used the Bluetooth technology for smart automation using a cell phone. But sending commands from software is not feasible and Bluetooth has a short range where if a user is not in the range of the system he cannot access and control the devices using the technology.

- Rahul Ashok in 2014 compared different technologies that are most popularly used in todays world. He has stated many applications of the technologies whereas on the otherhand he gave some disadvantages regarding each one of them. 
- Shiv Kumar in 2014 proposed a prototype which is android based and uses internet connectivity as well as Bluetooth technologies. It has an android application where we can select the technology by which we can access the system. But for the internet connectivity the user has to enter the IP address as well as the password and even for the Bluetooth we need to have the password. This is a bit long process as people now a days wants everything to happen at just a blink of an eye.

- Amrutha S in 2015 presented a system which is based on voice recognition. In this the system must be trained before hand with the commands. But if recognizing the voice fails, the user cannot access the system.

- K Vidyasagar in 2015 focused on the automation of home appliances using Bluetooth. In this the commands are sent through Bluetooth and the monitoring of the device status is done using IEEE 802.15.4 wireless device which is interfaced to the internet.

- Vinay sagar in 2015 presented an automation system using Intel Galileo. In this they have used the Wi-Fi technology which connects the web server with the sensors. Alarms will be raised when the sensor parameters are beyond the threshold parameters.

- Ravi Kishore in 2016 mainly concentrated on home security and home automation. This system sends alert to the owner over voice calls through internet when it senses human movement. If the person entering the house is a guest of the owner, then the system instead of raising an alert alarm makes arrangements for the guest such as opening the door, switching on the lights and fans etc., which reduces the work and involvement of the owner.

- Prof.H.B.Shinde in 2017 used android application which sends signals to the Arduino board. ESP8266 Wi-Fi module is used for communication between Arduino board and mobile application.

- Sudha Kousalya in 2018 aimed at building a smart home automation system using Wi-Fi connection. This prototype sends alert to the owner over E-mail using the internet.

This has become a major drawback of the present-day home automation systems. The touch-based automation system has overcome the drawback of the existing system.

\section{Proposed System}

The main focus of this system is touch sensor which helps the users to control the appliances from anywhere and at any time. This is the most optimal way of controlling and handling the devices. This Automation System uses Arduino and ESP-32 microcontroller and works with WiFi technology. The system is better from the scalability and flexibility point of view than the commercially available home automation systems.

The system has both hardware and software components. The hardware system includes ESP-32 microcontroller, bread board, sensor, LED and home appliances. The software system consists of an android application, Arduino IDE. The hardware components contribute to the handling and controlling of the home appliances through internet and the ESP-32 microcontroller helps to develop an interface between hardware components and software application.

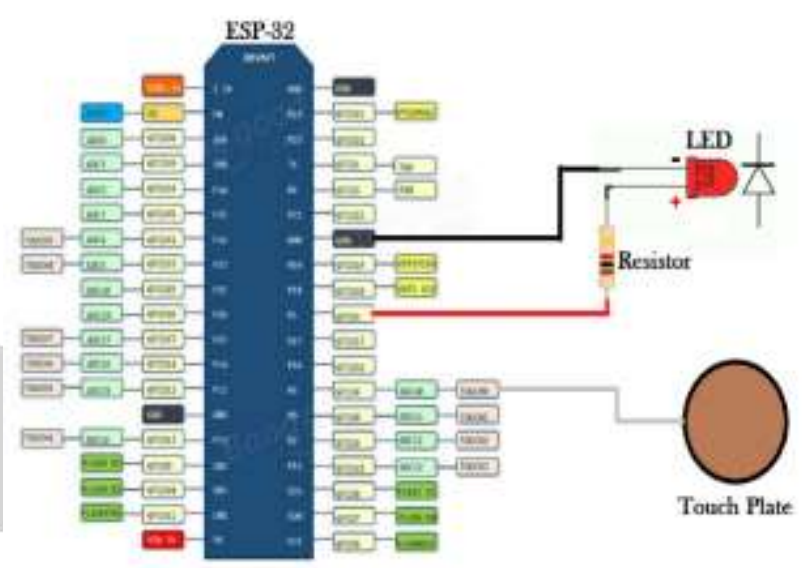

The connections are made as shown in the figure.

The ESP-32 microcontroller is placed on the bread board along with the touch sensor connected to the bread board. The LED is also connected to the bread board through which we get the output. Since our project is both touch based as well as Wi-Fi enabled, the ESP-32 microcontroller and the Arduino IDE software should be compatible with each other. There is only one input(Touch sensor) and one output(LED) in the circuit. After all the connections are done, the ESP-32 is powered up with 5 Volts supply or USB cables. This allows us to ON/OFF the home appliances through our mobile application with just one click from anywhere. The only requirement is that Wi-Fi should be integrated to the module. This helps the end users to access the appliances from anywhere around the world.

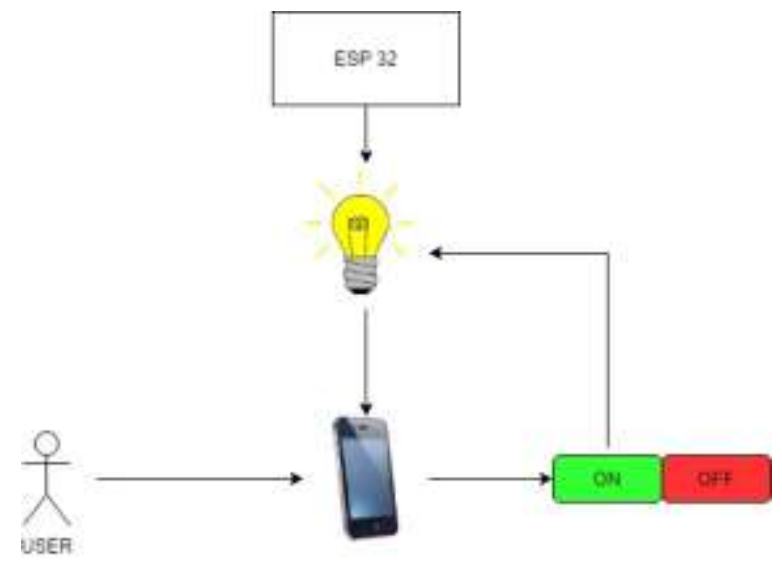


The LED through which we get the output is connected to the ESP-32 microcontroller. It is also supplied with a $5 \mathrm{~V}$ power supply. The user performs the task with the help of the android app which is developed with the help of the MIT app inventor. Each home appliance is controlled with the ON/OFF toggle buttons. The ESP-32 module has to be integrated with Arduino IDE software. Arduino IDE is a cross-platform application which is written in Java and coded in $\mathrm{C} / \mathrm{C}++$. Our aim is to control the home appliances with Touch as well as Wi-Fi. Since ESP-32 has in-built $\mathrm{Wi}-\mathrm{Fi}$ port we there is no need of an external Wi-Fi module. The touch sensor is also connected to the module. When we touch the sensor plate, the commands are transmitted to the module through the connecting wires and the readings of the GPIOs are directly taken by the touch function of the module. When the readings are set, it enables the LED to glow. This is shown in the android app with the ON button toggled.

\section{ESP32 with Touch}

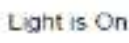

กN

ESP-32 is a great module for designing IoT applications and adding touch feature to it makes it even more smart. It is a microcontroller designed by Espressif. It is so convenient that even a novice can use it. ESP-32 contains Wi-Fi, Bluetooth, inbuilt touch sensing pins, temperature and hall sensors on board which makes it fit for IoT and smart home.

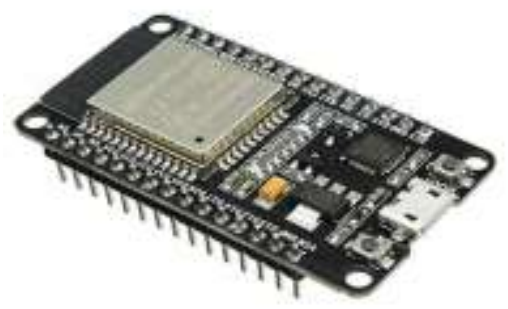

ESP-32 contains 10 Touch sensing general purpose $\mathrm{I} / \mathrm{O}$ (GPIO) pins. A touch sensor system is built on a substrate which carries electrodes and relevant connections under a protective flat surface. When a user touches the surface, the capacitance variation is triggered and a binary signal is generated to indicate whether the touch is valid. The 10 sensing pads are arranged in different combinations so that a larger area can be detected. The touchpad sensing process is under the control of a hardware- implemented finite-state machine(FSM) initiated by software.

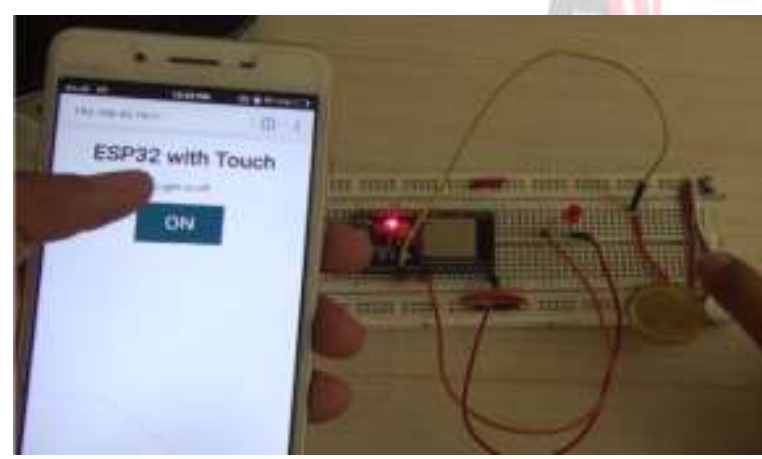

There are many challenges faced by the existing home automation systems. These include high manufacturing costs, high development costs, high installation costs, additional service and support costs, lack of automation standards, consumer unfamiliarity with technology and complex user interface. The advancement of time, technology and processing power leads to a considerable reduction in device cost and size.

\section{Features of the proposed system:}

- Reduced Installation costs

- Internet Connectivity

- Scalable and Expandable

- Security

3.ESP-32

\section{CONCLUSION}

This IOT based home automation system has become more efficient and flexible with the touch feature. It is so simple and can be accessed easily by the novice users. Due to its performance, simplicity, low cost and reliability touch-based home automation system is making its position in global market.

\section{Performance Analysis}

\begin{tabular}{|c|c|c|c|c|c|}
\hline $\begin{array}{l}\text { Parameters\Paper } \\
\mathrm{s}\end{array}$ & $\begin{array}{l}\text { Anitha } \\
\text { Chepuru }\end{array}$ & Ali Ziya & $\begin{array}{l}\text { Rahul } \\
\text { Ashok }\end{array}$ & $\begin{array}{l}\text { Amruth } \\
\text { a S }\end{array}$ & $\begin{array}{l}\text { Vin } \\
\text { ay } \\
\text { Sag } \\
\text { ar }\end{array}$ \\
\hline $\begin{array}{l}\text { Technology/Micr } \\
\text { ocontroller used }\end{array}$ & $\begin{array}{l}\text { Wi-Fi, } \\
\text { Bluetooth } \\
\text { /ESP-32 }\end{array}$ & $\begin{array}{l}\text { Wi- } \\
\text { Fi/PIC16 } \\
\text { F877A }\end{array}$ & $\begin{array}{l}\text { Bluet } \\
\text { ooth/ } \\
\text { Ardui } \\
\text { no } \\
\text { Mega } \\
2560 \text {, } \\
\text { Ardui } \\
\text { no } \\
\text { Ether } \\
\text { net } \\
\text { Sheild }\end{array}$ & $\begin{array}{l}\text { SMS/Zi } \\
\text { gbee }\end{array}$ & $\begin{array}{l}\text { Intel } \\
\text { Gali } \\
\text { leo }\end{array}$ \\
\hline Cost effective & Yes & Yes & Yes & Yes & Yes \\
\hline Flexible & Yes & Yes & Yes & Yes & Yes \\
\hline Energy usage & $5 \mu \mathrm{A}$ & $10 \mathrm{~mA}$ & $50 \mathrm{~mA}$ & $\begin{array}{l}100 \\
\text { MW }\end{array}$ & $\begin{array}{l}15 \\
W\end{array}$ \\
\hline User-friendly & Yes & Yes & Yes & Yes & Yes \\
\hline
\end{tabular}


We have compared our system with the other prototypes on which we have done the survey. We considered few parameters for the comparision. Every project has different technologies used. Though they have variant applications features, some barriers like the range or the internet connectivity shows some disadvantages of them. The touch feature of our system makes it unique from all the existing systems.

\section{REFERENCES}

[1] Vaishnavi S. Gunge, Pratibha S. Yalagi "Smart Home Automation: A Literature Review", International Journal of Computer Appliances(0975-8887), National Seminar on Recent Trends in Data Mining(RTDM 2016).

[2] Neha Malik, Yogita Bodwade "Literature Review on Home Automation System", International Journal of Advanced Research in Computer and Communication Engineering, ISO 3297:2007 Certified, Vol_6, Issue_3, March 2017.

[3] Rahul.S, S. Vignesh, A. Raam Kumar, MS V. Banupriya "Smart Home Automation System Using IOT and Bluetooth", International Journal of Pure and Applied Mathematics, Volume_116, No.27 2017, 143-148.

[4] "IoT Based Home Automation System using Arduino Board", International Research Journal of Engineering and Technology(IRJET), Volume_04, Issue_01, Jan- 2017.

[5] Ali Ziya Alkar Member, IEEE and Umit Buhur "An Internet Based Wireless Home Automation System for Multifunctional Devices", IEEE Trans. Consum. Electron., Volume_51, No. 4, pp. 1169-1174, Nov. 2005

[6] Amrutha S, Aravind S, Ansu Mathew, Swathy "Speech Recognition Based Wireless Automation of Home Loads", ISSN: 2319-5967 ISO 9001:2008 Certified International Journal of Engineering Science and Innovative Technology (IJESIT), Volume_4, Issue_1, January 2015

[7] K. Vidyasagar*, G. Balaji and K. Narendra Reddy "Android Phone Enabled Home Automation", Journal of Academia and Industrial Research (JAIR), Volume_4, Issue_2, July 2015

[8] Shiv Kumar, IEEE member, Seong Ro Lee, Senior IEEE member "Android Based Smart Home System with Control via Bluetooth and Internet Connectivity", $18^{\text {th }}$ IEEE Symposium on Consumer Electronics, $22^{\text {nd }}-25^{\text {th }}$ June,2014

[9] Ravi Kishore Kodali, Vishal Jain, Suvadeep Bose and Lakshmi Boppana "IoT Based Smart Security and Home Automation System", International Conference on Computing, Communication and Automation (ICCCA2016)
10] R.Piyare, M.Tazil "Bluetooth Based Home Automation System using Cell Phone", 2011 IEEE 15 International Symposium on Consumer Electronics

[11] Chathura Withanage, Rahul Ashok, Chau Yuen, Kevin Otto "A comparison of the popular home automation technologies”, pp. 1 - 11, may 2014

[12] Vinay sagar K N1, Kusuma S "Home Automation Using Internet of Things", International Research Journal of Engineering and Technology (IRJET) e-ISSN: 23950056 p-ISSN: 2395-0072, Volume_02 Issue_03 | Jan-2015

[13] Prof.H.B.Shinde, Abhay Chaudhari, Prafull Chaure, Mayur Chandgude, Pratik Waghmare " Smart Home Automation System using Android Application", International Research Journal of Engineering and Technology (IRJET) e-ISSN: 2395 -0056, p-ISSN: 23950072, Volume_04, Issue_04 | Apr -2017

[14] Sudha Kousalya, G. Reddi Priya, R. Vasanthi, B. Venkatesh "IoT Based Smart Security and Smart Home Automation", International Journal of Engineering Research \& Technology (IJERT), ISSN: 2278-0181 IJERTV7IS040026 Volume_7, Issue_04, April-2018. 